\title{
Upaya Meningkatkan Konsentrasi Belajar Siswa KMS (Kartu Menuju Sejahtera) Menggunakan Konseling Kelompok bagi Siswa
}

\author{
Mei Prihantini Diyah Ikawati \\ SMK Muhammadiyah Mlati \\ Jl. Kaliurang Km 6,5 Sono Sinduadi Mlati, Sleman, DIY, Indonesia \\ Email: fightmemey@gmail.com
}

\begin{abstract}
This research aims to know the effectiveness of group counseling service to improve the learning concentration of the students holding Road to Prosperity Cards (KMS-Kartu Menuju Sejahtera). The research employed action research in the implementation. The subject of the research is five students from grade VIII of SMP Negeri 15 Yogyakarta which were selected using purposive sampling technique. The data were collected using the quessionaire on learning concentration and observation guidelines. To examine the effectiveness of group counseling service, the data is analyzed using t-test formula. The data analysis results show the $t$-value of $9.215>t$ table (2.2776). The average score of the pretest on learning concentration was 145.4. The score improved at the post test on learning concentration, showing the average score of 167.4. Based on the research results, it can be concluded that group counseling service is effective to improve the learning concentration of the students holding Road to Prosperity Card. This research can be used by the teachers of guidance and counseling to help the students to improve their learning concentration through group counseling service.
\end{abstract}

Keywords: learning concentration, group counseling, classroom action research

\begin{abstract}
Penelitian ini bertujuan mengetahui keefektifan layanan konseling kelompok untuk meningkatkan konsentrasi belajar siswa KMS (Kartu Menuju Sejahtera). Pendekatan yang digunakan yaitu penelitian tindakan kelas (PTK). Subjek penelitian berjumlah lima siswa kelas VIII I SMP Negeri 15 Yogyakarta yang diambil dengan teknik purposive sampling. Instrumen pengumpulan data yang digunakan berupa angket konsentrasi belajar dan pedoman observasi. Teknik analisis data untuk menguji keefektifan layanan konseling kelompok dengan menggunakan rumus $t$-test. Hasil analisis data menunjukkan nilai t hitung sebesar 9,215 > t table $(2,776)$. Rata-rata hasil pretest konsentrasi belajar berada pada skor 145,4 dan rata-rata hasil posttest konsentrasi belajar meningkat pada skor 167,4. Berdasarkan hasil penelitian dapat disimpulkan bahwa layanan konseling kelompok efektif untuk meningkatkan konsentrasi belajar siswa KMS (Kartu Menuju Sejahtera). Hasil penelitian ini bermanfaat bagi guru bimbingan dan konseling untuk membantu siswa meningkatkan konsentrasi belajar melalui layanan konseling kelompok.
\end{abstract}

Kata kunci:konsentrasi belajar, konseling kelompok, penelitian tindakan kelas

\section{Pendahuluan}

Semua warga Indonesia berhak mendapatkan pendidikan yang layak, bukan hanya masyarakat menengah keatas yang mendapatkan pendidikan layak, masyarakat miskin pun berhak mendapatkan. Pemerintah haruslah segera merealisasikan program untuk pemerataan pendidikan bagi masyarakat miskin. Salah satu adalah melalui pemberian berbagai beasiswa bagi masyarakat tidak mampu. Pemberian beasiswa dapat diberikan dengan berbagai cara seperti beasiswa bagi pemegang Kartu Menuju Sejahtera (KMS). Beasiswa Kartu Menuju Sejahtera (KMS) ini telah dilaksanakan di Provinsi Daerah Istimewa Yogyakarta khusus di Kota Yogyakarta

Pendidikan adalah hal yang mendasar untuk meningkatkan kualitas kehidupan manusia dan menjamin kemajuan sosial.Pendidikan memainkan peran utama dalam membentuk kemampuan sebuah negara berkembang untuk menyerap teknologi modern dan untuk mengembangkan kapasitas agar tercipta pertumbuhan serta pembangunan yang berkelanjutan. Pendidikan yang mampu mendukung pembangunan bangsa dan negara dimasa yang akan datang adalah pendidikan yang mampu mengembangkan segenap potensi yang dimiliki siswa sehingga benar-benar selaras dengan program pembangunan dalam rangka mencapai tujuan nasional.

Sebagai identitas layanan bagi program jaminan pendidikan dan kesehatan, Pemerintah Kota (Pemkot) Yogyakarta mengeluarkan Kartu Menuju Sejahtera (KMS). Pemberian beasiswa melalui Kartu Menuju Sejahtera (KMS) ini telah berjalan termasuk di SMP Negeri 15 Yogyakarta. Berdasarkan hasil observas di sekolah tersebut, penulis menemukan data tentang rendahnya konsentrasi belajar pada siswa KMS. Terdapat 134 siswa Kartu Menuju Sejahtera (KMS) yang terdaftar di sekolah. Siswa-siswa tersebut masuk 
di kelas H, I, J dan sebagian kecil masuk di kelas lain. Siswa Kartu Menuju Sejahtera (KMS) berbeda-beda latar belakang keluarga tetapi karena terbiasa di lingkungan keras membuat siswa menjadi unik.

"Kuota siswa KMS SMP N 15 Yogyakarta ada sebanyak 134 kursi siswa. Sementara hingga saat ini jumlah yang mendaftar sudah ada sebanyak 215 calon siswa. Sehingga banyak yang sudah terlempar" Yogya (http://www.harianjogja.com, diakses Oktober 2015). Keluhan terkait prestasi dan daya saing siswa Kartu Menuju Sejahtera (KMS) bermunculan. Guru merasa kesulitan untuk mengajar karena kemampuan dasar siswa Kartu Menuju Sejahtera (KMS) yang rata-rata jauh di bawah siswa reguler lain. Belum lagi dengan motivasi rendah yang kemudian diikuti dengan perilaku membolos, tidur di kelas, mengabaikan tugas, berkelahi dengan teman, datang terlambat ke sekolah, mengganggu teman sekelas, kurang percaya diri.

Hasil observasi peneliti terhadap siswa kelas VIII SMP N 15 Yogyakarta pada bulan September 2015 diperoleh hasil bahwa secara umum siswa sama sekali tidak bisa berkonsentrasi belajar di kelas dan tidak mendengarkan penjelasan guru. Ditegur oleh guru hanya beberapa menit saja berjalan tetapi sehabis itu terulang kembali. Beberapa murid jalan-jalan saat pelajaran berlangsung kalau ditanya oleh guru dijawab meminjam pensil atau alasan lain. Ada yang mengganggu teman yang duduk di depan dan ada yang mengobrol dengan teman. Ada juga siswa yang izin ke kamar mandi tetapi ternyata ke kantin. Guru-guru pun pernah mengutarakan kalau anak-anak saat pelajaran sangatlah tidak kondusif.

Faktor yang dapat membawa keberhasilan anak didik dalam mencapai keberhasilan anak didik dalam mencapai tujuan pembelajaran adalah konsentrasi yang baik. Dengan berkonsentrasi, maka segala hal dapat terekam baik-baik di dalam memori otak dan selanjut dengan mudah dapat dikeluarkan pada saat-saat dibutuhkan.

Menurut Thohir, Nugraheni, Jannah (2012) diperoleh hasil bahwa metode problem solving dapat meningkatkan konsentrasi belajar siswa dalam pembelajaran matematika. Hal ini ditunjukkan pada peningkatan persentase minat siswa dan rata-rata hasil belajar siswa pada siklus II jika dibandingkan dengn siklus I. Siswa tidak hanya menerima materi yang diberikan guru, siswa harus aktif dalam kegiatan pembelajaran, secara tidak langsung konsentrasi siswa dalam belajar akan mempengaruhi hasil belajar siswa.

Belajar yang baik adalah orang yang dapat berkonsentrasi dengan baik. Seseorang sering mengalami kesulitan untuk berkonsentrasi di dalam kelas saat pelajaran berlangsung, hal ini disebabkan karena tidak memperhatikan dengan penuh pada saat mata pelajaran, tidak fokus ketika belajar, kurang berminat terhadap mata pelajaran yang dipelajari, terganggu oleh keadaan lingkungan (bising, keadaan yang semrawut, cuaca buruk dan lain-lain), pikiran yang kacau dengan banyak urusan atau masalah-masalah kesehatan (jiwa dan raga) yang terganggu (badan lemah), bosan terhadap mata pelajaran atau sekolah.

Layanan bimbingan dan konseling di sekolah merupakan salah satu program di dalam pendidikan yang diselenggarakan untuk membantu memberi pertolongan, mencegah atau mengatasi kesulitan-kesulitan kepada individu atau kelompok, dalam hal ini adalah siswa yang kurang konsentrasi belajar.Adapun macammacam konsep dalam Bimbingan dan Konseling, salah satu konsep atau metode yang dapat digunakan ialah metode konseling kelompok.

Konseling kelompok merupakan salah satu bentuk konseling dengan memanfaatkan kelompok untuk membantu, memberi umpan balik (feedback) dan pengalaman belajar.Suasana kelompok yaitu antar hubungan dari semua orang yang terlibat dalam kelompok, dapat merupakan wahana dimana masing-masing anggota kelompok itu (secara perorangan) dapat memanfaatkan semua informasi.

Tujuan penelitian ini adalah mengkaji keefektifan layanan konseling kelompok dalam meningkatkan konsentrasi belajar siswa. Konsentrasi belajar penting dimiliki oleh siswa agar mampu mencapai prestasi akademik yang optimal. Melalui layanan konseling kelompok, siswa dibantu untuk dapat menyelesaikan permasalahan yang menghambat konsentrasi belajarnya, dan siswa dapat bertukar pendapat dan belajar dari pengalaman anggota kelompok lainnya. Dengan demikian, hasil penelitian ini dapat dijadikan sebagai tambahan rujukan bagi konselor sekolah dalam meningkatkan konsentrasi belajar siswa melalui layanan konseling kelompok.

\section{Kajian Literatur}

\section{Konsentrasi Belajar}

Konsentrasi belajar merupakan pemusatan daya pikiran dan perbuatan pada suatu objek yang dipelajari dengan menghalau atau menyisihkan segala hal yang tidak ada hubungan dengan objek yang dipelajari.Rendah kualitas dan prestasi belajar, sebagian besar disebabkan oleh lemah kemampuan melakukan konsentrasi belajar.Siswa 
sering kali mengalami pikiran bercabang (duplikasi pikiran) saat melakukan kegiatan belajar. Pikiran bercabang bisa muncul tanpa disadari.Tentunya siswa pun merasa terganggu saat tidak mampu berkonsentrasi dalam belajar.Pada saat belajar, kadang kala tanpa disadari muncul kepermukaan alam pikiran mengenai masalah-masalah lama, keinginankeinginan lain atau terhambat menjadi pengganggu aktivitas belajar kita.

Menurut Dimyati dan Mudjiono (2013: 239) konsentrasi belajar merupakan kemampuan memusatkan perhatian pada pelajaran. Pemusatan perhatian tersebut tertuju pada isi bahan belajar maupun proses memperolehnya. Untuk memperkuat perhatian pada pelajaran, guru perlu menggunakan bermacam-macam strategi belajarmengajar, dan memperhitungkan waktu belajar serta selingan istirahat. Menurut Aunurrahman (2012: 180) konsentrasi belajar merupakan alah satu aspek psikologis yang seringkali tidak begitu mudah untuk diketahui oleh orang lain selain diri individu yang sedang belajar. Hal ini disebabkan kadang-kadang apa yang terlihat melalui aktivitas seseorang belum tentu sejalan dengan apa yang sesungguhnya sedang individu tersebut pikirkan.

Gangguan konsentrasi pada saat belajar banyak dialami oleh para pelajar terutama di dalam mempelajari mata pelajaran yang mempunyai tingkat kesulitan cukup tinggi, misalnya pelajaran yang berkaitan dengan ilmu pasti, atau mata pelajaran yang termasuk kelompok ilmu sosial. Kesulitan konsentrasi semakin bertambah berat jika seorang pelajar terpaksa mempelajari pelajaran yang tidak disukainya atau pelajaran.

Menurut Nuryana (2010: 4) konsentrasi belajar adalah "suatu aktivitas untuk membatasi ruang lingkup perhatian seseorang pada satu objek atau satu materi pelajaran". Pendapat selanjutnya oleh Syafrol (2013: 4) bahwa konsentrasi belajar adalah:

"Pemusatan perhatian pada suatu kegiatan sebagai kunci utama untuk mencapai tujuan belajar yang telah ditentukan, dan meningkatkan konsentrasi belajar adalah suatu gerakan yang timbul dari dalam diri untuk menuju pada pemusatan perhatian sehingga dapat mencapai tujuan pelajaran yang telah ditentukan, yang melibatkan fisik, mental, dan emosional."

Kegiatan belajar yang siswa lakukan dilakukan secara sungguh-sungguh dengan memusatkan seluruh panca indera penciuman, pendengaran, penglihatan dan fikiran.Bahkan yang sifatnya abstrak sekalipun yaitu perasaan dipusatkan pada pelajaran tesebut.

Menurut Hakim (2005: 1) mengatakan bahwa "konsentrasi belajar adalah orang harus berusaha keras agar segenap perhatian panca indera dan pikirannya hanya boleh terfokus pada satu objek saja". Selanjutnya konsentrasi yang efektif adalah suatu proses terfokusnya perhatian seseorang secara maksimal terhadap suatu objek kegiatan yang dilakukannya dan proses tersebut terjadi secara otomatis serta mudah karena orang yang bersangkutan mampu menikmati kegiatan yang sedang dilakukannya.

Inti dari melatih konsentrasi adalah melatih perhatian. Semakin sering memperhatikan sesuatu secara mendetail atau seksama, maka semakin baik konsentrasi. Pada dasar melatih konsentrasi adalah dilakukan dengan memperhatikan (secara seksama).Jika selama ini siswa merasa bahwa siswa sangat sulit untuk berkonsentrasi dan selalu mengalami konsentrasi yang terpecah, mungkin hal itu disebabkan karena siswa terbiasa untuk tidak pernah memperhatikan segala sesuatunya dengan seksama, pikirannya selalu terpecah dengan berbagai hal.Agar dapat berkonsentrasi dalam belajar di sekolah atau sulit mengerti yang dijelaskan oleh guru dan sebagainya maka siswa harus mengembangkan pola belajar aktif dan berani mengungkapkan ketidaktahuan pada halhal yang belum dimengerti kepada guru atau teman. Sebelum melakukan aktivitas belajar, pikiran harus benar-benar jernih dan harus benarbenar dalam kondisi yang fresh (segar).

Hasil analisis data penelitian dari Nugraheni Pratiwi tahun 2013 menunjukkan bahwa "ada peningkatan konsentrasi belajar siswa di sekolah melalui terapi Mozart pada siswa kelas VIII A SMP Negeri 2 Moyudan Sleman Yogyakarta Tahun Ajaran 2012/2013”.

Hasil analisis data penelitian dari Citra Ayesya Putri tahun 2012 menunjukkan bahwa "ada upaya untuk meningkatkan konsentrasi belajar siswa melalui layanan bimbingan kelompok pada siswa kelas VII C SMP Negeri 15 Yogyakarta Tahun Ajaran 2011/2012”.

Dari pengertian di atas dapat disimpulkan bahwa konsentrasi belajar adalah pemusatan perhatian terhadap sesuatu hal dengan menyampingkan semua hal lain yang tidak berhubungan, sehingga semua pikiran hanya tertuju pada suatu mata pelajaran saja dengan menyampingkan pelajaran-pelajaran yang lain.

\section{KMS (Kartu Menuju Sejahtera)}

Kartu Menuju Sejahtera (KMS) berfungsi sebagai identitas layanan bagi program jaminan pendidikan dan kesehatan. Kartu Menuju Sejahtera (KMS) bisa digunakan untuk penyaluran beasiswa bagi siswa tidak mampu dan layanan jaminan kesehatan (askeskin) serta berfungsi memudahkan pembagian beras (raskin).

Sesuai kebijakan Pemerintah Kota Yogyakarta, Kartu menuju Sejahtera (KMS) 
diperuntukkan bagi keluarga miskin (gakin) berKTP (Kartu Tanda Penduduk) Kota Yogyakarta sesuai dengan daftar gakin hasil verifikasi dan updating data gakin tahun 2007. Proses verifikasi data gakin di lapangan untuk mengetahui keluarga masuk dalam suatu kategori, diantara: kategori fakir miskin (keluarga menuju sejahtera 1), miskin (keluarga menuju sejahtera 2), hampir miskin (keluarga sejahtera 3) dan tidak miskin (keluarga sejahtera), kesemua kategori tersebut merupakan kelompok masyarakat yang digolongkan miskin dan ditetapkan layak sebagai penerima berbagai jaminan, terutama jaminan kesehatan dan jaminan pendidikan.

Dalam Peraturan Walikota Yogyakarta No.19 Tahun 2010 Tentang Pedoman Pemberian Jaminan Pendidikan Daerah tidak disebutkan tentang batas minimal nilai yang harus dimiliki seorang anak keluarga pemegang Kartu Menuju Sejahtera (KMS).Sekolah menerima calon peserta didik baru dari golongan Kartu Menuju Sejahtera (KMS) dengan nilai berapa pun.Hal tersebut kemudian mengakibatkan rata-rata siswa Kartu Menuju Sejahtea (KMS) yang mendaftar memiliki nilai yang jauh di bawah standar sekolah.

Dalam bidang pendidikan, semua peserta didik memiliki hak untuk mendapatkan dan mencapai prestasi. Dikaitkan dengan hal tersebut, pemerintah Kota Yogyakarta mengeluarkan Peraturan Walikota Yogyakarta No.19 Tahun 2010 Tentang Pedoman Pemberian Jaminan Pendidikan Daerah yang menyatakan bahwa :

"Tujuan diberikannya Jaminan Pendidikan Daerah adalah agar tidak ada anak usia sekolah dari keluarga pemegang KMS yang tidak bersekolah karena alasan biaya.Jaminan Pendidikan Daerah adalah bantuan biaya pendidikan bagi keluarga pemegang KMS berupa biaya operasional, biaya investasi, dan biaya pribadi.Biaya operasional terdiri dari belanja pegawai serta belanja barang dan jasa.Biaya investasi adalah belanja modal yang digunakan untuk pengeluaran pembelian/pengadaan pembangunan aset tetap berwujud yang mempunyai nilai manfaat lebih dari 12 bulan.Biaya pribadi adalah biaya yang digunakan peserta didik untuk pengeluaran pembelian keperluan yang secara tidak langsung mendukung kegiatan belajar mengajar, yang terdiri dari seragam dan buku."

Peraturan tersebut menjelaskan bahwa Pemerintah Kota Yogyakarta memberikan hak dan kesempatan untuk berprestasi pada peserta didik dari keluarga pemegang Kartu Menuju Sejahtera (KMS).Setiap jenjang pendidikan di Yogyakarta, diwajibkan menyediakan kuota khusus bagi siswa KMS.
Pemerintah Kota Yogyakarta memberikan akses khusus bagi siswa Kartu Menuju Sejahtera (KMS) dalam penerimaan peserta didik baru (PPDB) setiap tahunnya, dengan membedakan jalur pendaftaran sehingga mereka hanya bersaing antar pemegang Kartu Menuju Sejahtera (KMS) dengan kuota tertentu.

\section{Konseling Kelompok}

Salah satu jenis layanan yang dapat diberikan oleh konselor kepada siswa yaitu layanan konseling kelompok. Menurut Prayitno (2004: 311) layanan konseling kelompok secara tidak langsung dapat dikatakan sebagai layanan konseling perorangan yang dilaksanakan dalam suasana kelompok. Menurut Winkel (2004: 589) konseling kelompok merupakan bentuk khusus dari layanan bimbingan dan konseling yaitu wawancara konseling antara konselor profesional dengan beberapa orang sekaligus yang tergabung dalam suatu kelompok kecil. Konseling kelompok dapat pula diartikan sebagai proses konseling yang dilakukan dalam situasi kelompok, dimana konselor berinteraksi dengan konseli dalam bentuk kelompok yang dinamis untuk memfasilitasi perkembangan individu dan atau membantu individu dalam mengatasi masalah yang dihadapinya secara bersama-sama Kurnanto (2013: 9). Berkaitan dengan judul penelitian, maka dapat dijelaskan pengertian konseling kelompok sebagai suatu proses pemberian bantuan kepada sekelompok individu yang mengalami masalah relatif sama kemudian didiskusikan pemecahan masalahnya sehingga permasalahan sekelompok individu tersebut dapat terselesaikan dengan baik serta dapat meningkatkan konsentrasi belajar siswa KMS (Kartu Menuju Sejahtera) di sekolah.

Menurut Wibowo (2005: 86) terdapat empat tahap dalam pelaksanaan konseling kelompok, yaitu tahap permulaan, tahap transisi, tahap kegiatan, tahap pengakhiran.

1. Tahap permulaan (Begining Stage)

Pada tahap ini yang dilakukan konselor adalah mempersiapkan terbentuk kelompok. Selain itu konselor juga konselor harus mampu menimbulkan minat yang mendukung bagi terbentuk kelompok yang meliputi pemberian penjelasan pengertian, tujuan, dan kegunaan konseling kelompok, ajakan untuk memasuki dan mengikuti kegiatan. Demikian dalam tahap ini dapat dikatakan sebagai tahap pengenalan, tahap perlibatan diri, tahap menentukan agenda, tahap membentuk norma kelompok, dan tahap penggalian ide dan perasaan.

2. Tahap transisi (Transition Stage)

Tahap ini merupakan tahap yang sangat singkat, yang terjadi setelah proses 
pembentukan atau permulaan. Tahap ini ditandai dengan muncul ekspresi sejumlah emosi dan interaksi anggota kelompok.

3. Tahap kegiatan (WorkingStage)

Tahap ini merupakan tahap inti dari pelaksanaan konseling kelompok, yang ditandai dengan keterlibatan secara aktif dari setiap angota kelompok dalam membahas, mempelajari materi baru, mendiskusikan berbagai permasalahan yang muncul dan mempraktekan perilaku-perilaku yang baru.

4. Tahap pengakhiran (Termination Stage)

Secara umum dapat dikatakan bahwa tahap pengakhiran tepat dilakukan saat tujuan dalam kegiatan konseling kelompok telah tercapai yang ditandai dengan dirumuskan perilaku positif yang dapat menjadi pemecahan suatu permasalahan yang menjadi topik kajian dalam diskusi kelompok dan perilaku tersebut telah dipraktekan dalam kehidupan sehari-hari diluar kelompok. Perlu diketahui bahwa dalam tahap ini yang paling penting adalah kemampuan konselor dalam mentransfer atau merealisasikan apa yang anggota kelompok pelajari dalam kelompok dapat diaplikasikan kedalam kehidupan sehari-hari mereka.

\section{Metode Penelitian}

Pendekatan penelitian yang digunakan dalam penelitian ini adalah penelitian tindakan kelas (classroom action research). Subjek penelitian siswa kelas VIII I SMP Negeri 15 Yogyakarta yang mengalami konsentrasi belajar rendah. Subjek penelitian ditentukan dengan teknik purposive sampling. Instrument pengumpulan data yang digunakan berupa angket konsentrasi belajar dan pedoman observasi. Data yang tekumpul dianalisis secara deskriptif kuantitatif maupun kualitatif.

\section{Hasil Penelitian Dan Pembahasan}

Berdasarkan hasil analisis menggunakan uji t sampel berpasangan diperioleh nilai $\mathrm{t}$ hitung = 9,215> $\mathrm{t}$ table (2,776) yang berarti bahwa hipotesis penelitian diterima yaitu "ada peningkatan konsentrasi belajar siswa Kartu Menuju Sejahtera (KMS) menggunakan konseling kelompok kelas VIII I di SMP Negeri 15 Yogyakarta angkatan 2015/2016". Hasil penelitian ini menunjukkan bahwa layanan konseling kelompok bantuan terhadap siswa yang mengalami tingkat konsentrasi belajar siswa yang rendah yang dapat meningkat karena ada pemahaman baru yang diperoleh melalui konseling kelompok.
Hasil analisis menunjukkan bahwa ke lima subjek telah mengalami peningkatan skor, dari hasil rata-rata pretest 145,4 dan meningkat menjadi 167,4 setelah diadakan perlakuan konseling kelompok, artinya ada peningkatan sebesar meningkat menjadi 22 point. Mereka juga mampu merubah konsentrasi belajar saat di dalam kelas, seperti: tenang di dalam kelas, mengurangi frekuensi keluar masuk kelas saat pelajaran berlangsung, dan tidak membawa HP ke sekolah.

Meningkat konsentrasi belajar siswa KMS (Kartu Menuju Sejahtera) dapat juga diketahui berdasarkan pada hasil observasi.Hasil observasi pada konseling kelompok diketahui ada peningkatan respon dan aktivitas siswa pada setiap siklus tindakan.Pada siklus I pelaksanaan layanan konseling kelompok untuk meningkatkan konsentrasi belajar siswa KMS (Kartu Menuju Sejahtera) diketahui masih ada 2 siswa dari 5 siswa yang mendapat penilaian cukup.Hal ini menunjukkan bahwa sebagian besar siswa berada pada kategori cukup maksud cukup antusias mengikuti kegiatan konseling kelompok.Siswa terkadang mengikuti arahan yang diberikan peneliti saat konseling kelompok, siswa cukup memperhatikan saat konseling.Siswa mengikuti dengan cukup senang. Siswa mengikuti dengan cukup tenang. Pada siklus II respon siswa sudah berada pada kategori baik. Siswa datang tepat waktu.Siswa mengikuti arahan yang diberikan peneliti saat konseling kelompok, siswa memperhatikan saat konseling. Siswa mengikuti dengan senang. Siswa mengikuti dengan tenang. Siswa terbuka terhadap peneliti.Selain hasil dari observasi mengenai respon siswa pada saat layanan konseling kelompok juga dapat dilihat pada skor angket sebelum diberi tindakan dan setelah diberi tindakan terlihat ada peningkatan, artinya konsentrasi belajar siswa meningkat setelah diberikan layanan konseling kelompok. Pemahaman dan konsentrasi belajar siswa pada siklus kedua lebih baik daripada siklus pertama. Pada saat belajar di kelas ada peningkatan kualitas siswa dalam mengikuti mata pelajaran. Pada mata pelajaran IPA mempunyai skor ratarata sebesar 40,4 dan pada mata pelajaran Matematika ada peningkatan dengan rata-rata sebesar 1,2.

Faktor internal yang berupa keadaan jasmani dan rohani.Keadaan jasmani meliputi kondisi badan yang sehat atau bebas dari penyakit serius, siswa cukup tidur dan beristirahat, dan seluruh panca inderanya berfungsi dengan baik. Kedaan rohani seperti taat beribadah sebagai penunjang ketenangan dan pengendalian diri, tidak emosional, tidak mengalami masalah yang terlalu berat, tidak emosional, memiliki rasa percaya diri yang cukup, tidak mudah putus asa, bebas dari berbagai gangguan mental seperti rasa takut, was- 
was dan gelisah. Menurut penelitian Amalia Cahya Setiani (2014: 89-91) gangguan kesehatan jasmani: seperti kurang tidur dan kelelahan setelah berolahraga dan sedang dalam keadaan lapar sangat berpengaruh pada konsentrasi belajar siswa, timbulnya perasaan negatif: perasaan tidak enak yang ditimbulkan oleh adanya rasa khawatir karena suatu hal sehingga menyita sebagian besar perhatian siswa, lemahnya minat dan motivasi pada pelajaran: cara mengajar guru yang membosankan dan guru yang jarang mengajar di kelas membuat siswa kurang bersemangat untuk mengikuti pelajaran membuat siswa mudah terpengaruh pada hal-hal lain yang lebih menarik perhatian ketika proses belajar berlangsung, bersifat pasif dalam belajar: siswa bersifat pasif dalam belajar, tidak pernah bertanya ketika ada bagian materi pelajaran yang tidak dimengerti siswa.

Faktor eksternal yang mempengaruhi konsentrasi belajar yang lain adalah suasana rumah. Suasana rumah yang terlalu gaduh atau terlalu ramai, udara yang bebas dari polusi, penerangan di sekitar lingkungan yang cukup sehingga tidak menimbulkan kesukaran bagi pandangan mata, serta tersedianya fasilitas yang cukup menunjang kegiatan belajar (ruangan yang bersih, kursi, meja, dan peralatan untuk keperluan sekolah). Menurut penelitian Saifaturrahmi Hidayat (2010: 10) musik klasik ketika digunakan sebagai musik latar belakang pada saat belajar, membaca, atau menulis, mengakibatkan individu menjadi fokus dan berkonsentrasi, karena musik klasik dapat meningkatkan perhatian, retensi dan memori, memperpanjang waktu untuk fokus terhadap pelajaran, dan mengembangkan kemampuan berfikir. Dari hasil pengamatan yang dilakukan terhadap kelompok ekperimen, terlihat bahwa subjek pada kelompok tersebut, menampilkan kondisi yang nyaman, santai dan rileks ketika membaca serta lebih tenang dari pada subyek pada kelompok kontrol. Hal ini membuktikan bahwa musik klasik mampu menciptakan susana yang rileks ketika subyek pada kelompok eksperimen melakukan kegiatan membaca. Kondisi yang rileks tersebut mempermudah subyek dalam berkonsentrasi, dengan daya tahan konsentrasi yang baik akan meningkatkan kemampun subyek dalam belajar.

\section{Simpulan}

Berdasarkan hasil penelitian maka dapat disimpulkan bahwa konseling kelompok efektif meningkatkan konsentrasi belajar siswa. Hasil penelitian ini bermanfaat bagi konselor untuk membantu siswa meningkatkan konsentrasi belajar melalui konseling kelompok.

\section{Referensi}

Ahmadi, Abu, dan Widodo Supriyono. (2004). Psikologi Belajar. PT. Rineka Cipta, Jakarta.

Arikunto, Suharsimi. (2010). Prosedur Penelitian Suatu Pendekatan Praktik Edisi Revisi. Jakarta: Rineka Cipta.

(2006). Prosedur Penelitian. Jakarta: Rineka Cipta

Dimyati, dan Mudjiono. 2013. Belajar dan Pembelajaran. Jakarta: Rineka Cipta.

Fanu, James Le. (2009). Deteksi Dini MasalahMasalah Psikologi Anak. Yogyakarta: Think

Hakim, Thursan. (2003). Mengatasi Gangguan Konsentrasi. Jakarta : Puspa Swara.

http://www.harianjogja.com/baca/2015/07/01/ppd b-smp-sleman-6-800-kuota-siswa-barusmp-terpenuhi-734021, diakses Oktober 2015.

Kurnanto, M. Edi. (2013). Konseling Kelompok. Bandung: Peneribit Alfabeta.

Natawidjaja, Rochman. (2009). Konseling Kelompok Konsep Dasar \& Pendekatan. Bandung: Rizqi Press.

Nurihsan, Juntika A. (2007). Strategi Layanan Bimbingan dan Konseling. Bandung: PT Refika Aditama.

Pratiwi, Nugraheni. (2013). Meningkatkan Konsentrasi Belajar Siswa melalui Meotde Terapi Musik Mozart pada Siswa Kelas VIII SMP Negeri 2 Moyudan Sleman Tahun Ajaran 2012/2013. Skripsi tidak diterbitkan. Fakultas Keguruan dan Ilmu Pendidikan Jurusan Bimbingan dan Konseling Universitas Ahmad Dahlan.

Prayitno dan Erman Amti. (2004). Dasar-Dasar Bimbingan dan Konseling. Jakarta: Rineka Cipta.

Putri, Citra Ayesya. (2012). Upaya Peningkatan Konsentrasi Belajar Siswa melalui Layanan Bimbingan Kelompok pada Siswa Kelas VII SMP Negeri 15 Yogyakarta Tahun Ajaran 2011/2012”. Skripsi tidak diterbitkan. Fakultas Keguruan dan Ilmu Pendidikan Jurusan Bimbingan dan Konseling Universitas Ahmad Dahlan.

Rahman, Hibana. (2003). Bimbingan dan Konseling Pola 17. Yogyakarta: UCY Press.

Rusyan, Tabrani. (1989). Pendekatan dalam Proses Belajar Mengajar. Bandung: Remaja Rosdakarya.

Setiani, Amalia Cahya. (2014). Meningkatkan Konsentrasi Belajar Melalui Layanan Bimbingan Kelompok Pada Siswa Kelas VI SD Negeri 2 Karangcegak, Kabupaten 
KONSENTRASI BELAJAR, KONSELING KELOMPOK

Purbalingga Tahun Ajaran 2013/2014.

Skripsi tidak diterbitkan. Jurusan Bimbingan dan Konseling Fakultas Ilmu Pendidikan Universitas Negeri Semarang.

Supriyo. (2008). Studi Kasus Bimbingan Konseling. Semarang: CV. Nieuw Setapak. Syafrol, Danillah. (2013). Peningkatan Konsentrasi Belajar Anak Autis Dalam Berhitung Melalui Keterampilan Meronce". Jurnal Pendidikan dan Pembelajaran, Vol. 2 (9).
Wibowo, Eddy. (2005). Konseling Kelompok Perkembangan. Jakarta: Unres Pres.

Winkel, W.S. (2005). Bimbingan dan Konseling di Intitusi Pendidikan, Edisi Revisi. Jakarta: Gramedia.

Yusuf, Syamsu. (2009). Program Bimbingan dan Konseling di Sekolah. Bandung: Rizqi Press.

Thohir, K., Nugraheni, P., Jannah, M.H. (2012). Peningkatan Konsentrasi Belajar Menggunakan Metode Problem Solving. Jurnal EKUIVALEN, Vol 7 (2). 